\title{
Between semiotic linguistics and narratology: Objective grounding and similarity in essayistic translation
}

\author{
Patrick Goethals ${ }^{1}$ \\ University College Ghent/Ghent University \\ In memoriam Christophe Halsberghe
}

In this article, I will show how the description of meaning in translated texts can be enriched by combining insights from semiotic linguistics and narratology. Concretely, I will focus on the phenomenon of 'grounding' as it is described in Cognitive Grammar. Special attention will be paid to 'objective grounding'. I will claim that this phenomenon plays a central role in essayistic translation, as it reflects one of the core characteristics of this type of translation, i.e. the search for similarity. The analysis of objective grounding will allow us to develop this notion, describing similarity at product level but also at the communicative process level. In the final section, I will try to link the search for similarity with psychological notions such as empathy and anxiety.

\section{Introduction}

Methodologically, this paper aims to contribute to the field of Translation Studies through a close and systematic comparison of linguistic choices made by different translators. The analysis presents an empirical description with an interdisciplinary interpretive approach, combining insights from Cognitive Grammar on the one hand, and narratology on the other. I hope to show that the encounter between semiotically motivated linguistic description and narratologically motivated translation research questions is a fruitful field to explore (see also Koster 2000 and Bosseaux 2007).

Concretely, I will analyze how the "voice" of the author is rendered in translated texts (Munday 2008), and, more precisely, how the translator attempts to appropriate "the deictic centre of the implied author" (Semlali 2007). I will do so by analyzing referential expressions known in Cognitive Grammar (CG) as "grounding phenomena" (Brisard 2002, Langacker 2002).

As a final methodological suggestion, I will use notions like "empathy" and "anxiety" in the interpretation of the translator's decisions. Using these notions, which go beyond the descriptive scope of this paper, I want to emphasize the central role of the individual translator, and point out psychological factors to complement linguistically oriented corpus translation studies. 


\subsection{Semiotic linguistics and Translation Studies}

Once in a while, the role of linguistics within Translation Studies (TS) is severely criticized. As far as formal linguistics is concerned, this criticism seems justified. Indeed, it is hard to see how frameworks dissociating form and meaning could give new insights into the translation process. However, a critical attitude towards formal(istic) linguistics should not lead to a lack of awareness of other, and more recent, insights. In particular, TS should especially be aware of the frameworks that fall under the umbrella of 'semiotic linguistics' and do not dissociate form and meaning, but, on the contrary, explicitly connect both dimensions. Well-known examples are Systemic Functional Grammar (Halliday), Cognitive Grammar (Langacker), or Construction Grammar (Goldberg).

The fundamental contribution that semiotic linguistics should make to TS, and especially to descriptive TS, is to provide a linguistic 'tool kit' to describe the semantics of formally identifiable phenomena (see also Vandepitte 2007). Categories like tense, deixis, or personal pronoun systems, to name but a few, are highly complex systems that allow variations which cannot be described by means of rough TS notions such as 'explicitation', 'implicitation' or 'normalization'. From a linguistic viewpoint at least, these are rather pre-theoretic notions, and not sufficiently fine-grained to describe the oppositions within the semiotic categories.

\subsection{Grounding expressions, deictic centre and translation}

The present study will compare the French (FR) and English (EN) translations of a Spanish essay by Ortega y Gasset, concentrating on referential expressions as illustrated in (1):

(1) Hay muchos problemas en España/ en este país/ en nuestro país

Il y a beaucoup de problèmes en Espagne/ dans ce pays/ dans notre pays

There are a lot of problems in Spain/ in this land/ in our land

As will be described in a more systematic way in section 2, the different nominal phrases give different information about the deictic centre from which the scene is conceptualized (in Cognitive Grammar (CG), they are called grounding terms). Roughly speaking, the sentence with en España (in Spain) does not give any information, for it may be said by anyone, or anywhere. To give a correct interpretation to the sentence with (deictic) en este país, on the other hand, we are supposed to know where the speaker is. The sentence with en nuestro país (in our land), finally, seems similar to the preceding sentence with en este país, because its interpretation also varies depending on the deictic centre, or more particularly on the question 
'who is speaking?'. Yet, CG will distinguish between both constructions arguing that only in the construction with 'our' there is an explicit reference to a participant of the speech event.

Another introductory remark concerns the role that the deictic centre plays in the translation of essays from a narratological point of view. I will use the schema offered by Munday $(2008: 12),{ }^{2}$ but similar proposals may be found in Schiavi 1996 and O'Sullivan 2003 (Figure 1):

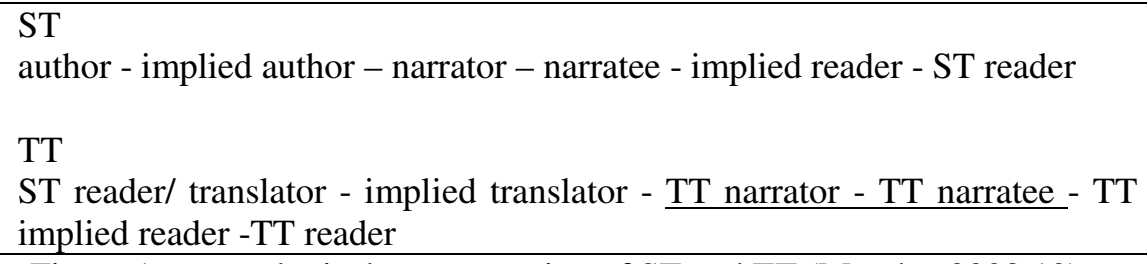

Figure 1: narratological representation of ST and TT (Munday 2008:12)

In an essay, the implied author (the author as (s)he is perceived by the reader) and the narrator normally coincide: ${ }^{3}$ when the narrator says I think, we are allowed to believe that it is the (implied) author who holds this belief. The deictic centre also includes the narratee, who coincides by default with the implied reader (the image of the readership construed by the author or the real reader). When the narrator says in our country, we will interpret our as referring to the implied author and implied reader. This is called extradiegetic anchoring of the textual deictic centre. In fiction, the deictic centre is shifted away from the real-world situation and anchored intradiegetically, which means that the reader is not supposed to identify the narrator with the implied author (see Herman 2002: 271-4 and 331-71 for a far more detailed account of deictic centre shift in fiction).

Using the notions introduced by Nord 1997, a translated essay is normally a type of documentary translation, rather than instrumental translation. This means that the deictic centre of the TT remains anchored to the implied author and/or implied reader of the ST: the referential denotation of I think and our country does not change and still concerns the implied author and/or reader of the ST. In the case of an instrumental translation, for example a translation of instructions or advertisements, the deictic centre is reset. Therefore, the reader of the translated advertisement will interpret our country as referring to his/her own country. Literary translation is like documentary translation, since the deictic centre is not reset, but of course, the intradiegetic nature of the deictic centre causes the anchoring to function in a more complex and above all fuzzier way.

What is important for us is that in essayistic translation, the deictic centre in principle must remain unchanged and clearly identifiable (the "voice" of the original author is even a salient aspect of the text). What may change, nevertheless, is the way in which the deictic centre is evoked. This is exactly what I will examine. 


\section{Cognitive Grammar and the 'grounding' phenomena}

Let me briefly explain some basic notions of $\mathrm{CG}$ in order to understand a CG analysis of the referential expressions in (1). These notions are 'scope' \& 'profile', 'viewing arrangement', and 'grounding' (distinguishing between 'zero grounding', 'objective grounding' and 'subjective grounding').

The best-known concepts are 'scope' and 'profile'. The basic idea is that the semantics of a linguistic element (a lexical item or a grammatical construction) profiles a part of a larger scene. Both the activation of the larger scene ('scope') and the profiling of a specific part of it ('profile') are part of the semantics of the element. The examples given by Langacker 2002 to illustrate this point are lid and to arrive. The noun lid profiles the object that covers another object: the latter is not profiled by the word lid but nevertheless belongs to the larger scene that is evoked (i.e. its scope). The verb to arrive profiles the end of a movement: the movement itself is not part of the profile of the lexical item but of the scope.

(a)

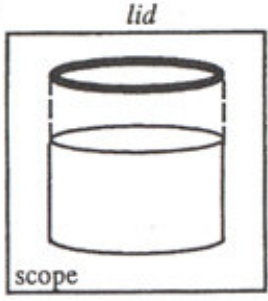

(b)

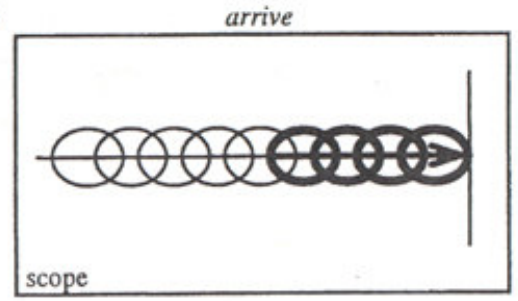

Figure 2: 'scope' and 'profile' (Langacker 2002:5)

The concept of 'viewing arrangement' brings us to CG drawing parallels between the mental construal of meaning and the mental representation of perception. CG maintains that, in the same way as something is always perceived from a certain perspective, mental meaning is always construed from a particular point of view as well. The 'point of view' is an inherent part of the mental construal of meaning. This is called the 'viewing arrangement'. The viewing arrangement may take different forms but the default case is when a certain state of affairs is viewed from the point of view of the speaker at the moment when (s)he speaks. This speech situation is called the 'ground'. In every clause we find linguistic elements that relate the clause to the ground (this phenomenon is called 'grounding'):

The essential property of a nominal or a finite clause is that it not only profiles an instance of the thing or process type in question, but also indicates the status of this instance vis-à-vis the ground. I use 
the term ground for the speech event, its participants, and its immediate circumstances. In one way or another, the elements that serve a grounding function specify the relationship between some facet of the ground and the entity profiled by the nominal or clause. (Langacker 2002: 7)

The combination of the concepts of 'scope', 'profile' and 'grounding' will now enable us to distinguish between the NPs Spain, this land and our land. In the NP Spain, the deictic centre, or ground, is not evoked: the NP may be pronounced by any speaker, anywhere, anytime, and it will have the same denotational meaning. Following CG terminology, we will say that the ground remains out of the scope of the expression or that it is a case of zero grounding. The NP is 'grounded' when the ground becomes part of the meaning of the expression. When the ground is part of the explicitly highlighted meaning, when it is explicitly mentioned (focus), and not only evoked as part of the larger scene (scope), the expression is said to be $o b$ jectively grounded. The term objective means that it is part of what is 'put on stage': it is part of what is viewed, and not part of the viewing arrangement. This is the case with our land because of the self-referential our (another example would be you as a form of addressing the reader). In the third case, this land, the ground is not part of the focus, for it is not explicitly mentioned, but only presupposed as a necessary element in order to interpret the meaning of this. That is why the ground is said to be part of the scope of the expression. This is called subjective grounding because the ground is part of the viewing arrangement and not of what is viewed. The difference between subjective and objective grounding is that in the former case the viewing arrangement is part of the scope and in the latter case the focus of the expression.

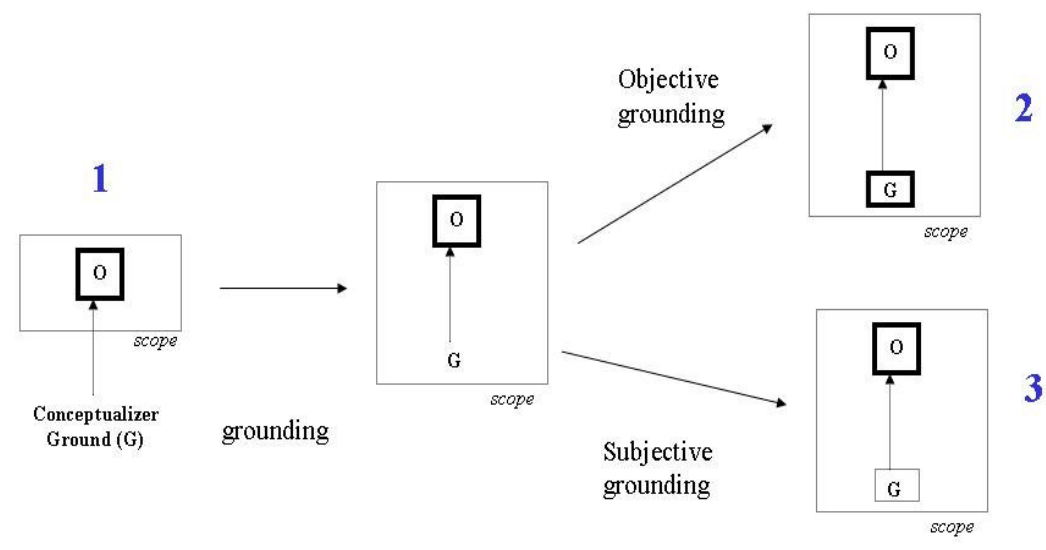

Figure 3: (1) zero grounding Spain, (2) objective grounding our land, and (3) subjective grounding this land 
The result of this approach is a tripolar system. As we see in figure 4, it is possible to make more subdivisions, but these oppositions are beyond the scope of this paper.

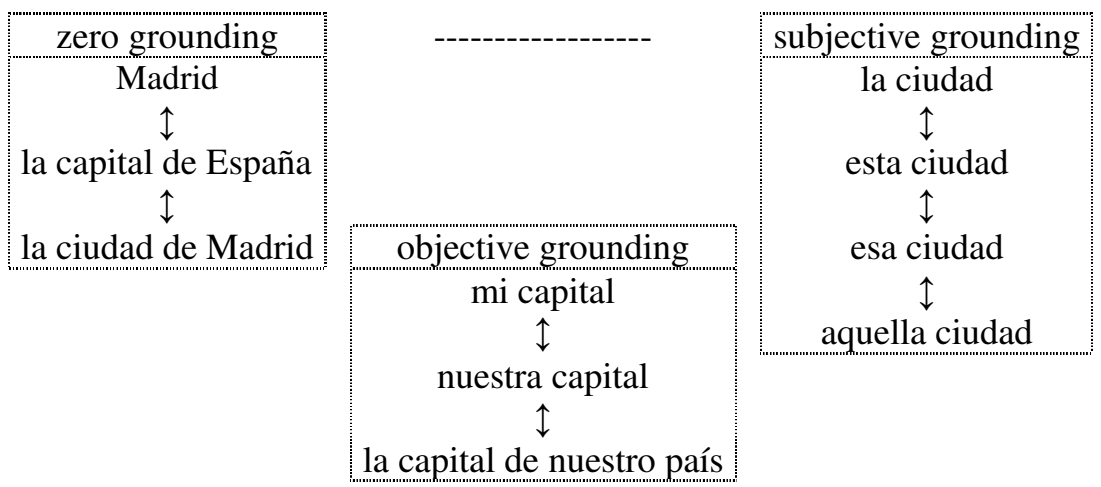

Figure 4: some instances of zero, objective and subjective grounding

\section{Case study: objective grounding in two translations of the essay $L a$ ausencia de los mejores (Ortega y Gasset 1922)}

\subsection{Introduction}

I will now apply the concepts outlined above to the EN and FR translations of the chapter La ausencia de los mejores of España invertebrada, by Ortega y Gasset (1922). The FR translation by Mathilde Pomès was published as an article in Bibliothèque Universelle et Revue de Genève (January 1930). The EN translation was written by Mildred Adams, and published as part of the book Invertebrate Spain (1937). The original essay counts 4,678 words.

The essay gives an analysis of Spain's decline. The central claim is that the influence of the intellectual elite in the history of Spain has been insufficient. The next quote from the EN translation reflects the core idea of the essay well:

I think that what I said above will be better understood now. Everything in Spain has been done by the people, and what they did not do has been left undone. But a nation cannot consist solely of the common people. It needs an eminent minority. [...] The absence of the "best people," or at least their scarcity, runs through our whole history and has kept us from ever being like other nations under similar conditions, a completely normal people. (p. 85)

The quote also reveals the documentary character of the translation, since the ground or deictic centre of the TT echoes the grounding conditions of 
the source text. When we read I think, I said, our whole history, or has kept us from, there is no doubt that the first person forms refer to the implied author (I), and the implied reader (our/us). This, however, does not mean that the translator always has to use the same category of grounding elements: it is perfectly possible to introduce alternations between zero, objective and subjective grounding without changing the deictic centre of the construction.

In the database, I included all examples of objective and zero grounding found in either the ST or in either of the TTs (FR/EN). Within the category of zero grounding, only the references to the source text culture (i.e. Spain) were selected. The examples of subjective grounding are included when they correspond to an objective or zero grounding device in the ST or in one of the TTs. The reason why not all subjective grounding elements were included is that subjective grounding is a ubiquitous phenomenon, since every definite NP and every tensed VP is grounded, and as such, it is not a suitable criterion for selecting the examples in a corpus.

\subsection{Corpus results}

Before proceeding to a systematic analysis of the two translations, let us first look at examples (2)-(5) that illustrate some of the different translation possibilities. In the examples, italics are used to highlight the relevant fragments. The TT fragments that imply a categorial change with respect to the ST grounding are also underlined.

In example (2), the ST objective grounding nuestra historia is maintained in both translations, although it would be possible to use zero grounding devices like for example l'histoire espagnole or Spain's history instead of notre histoire and our history.

(2) intenté mostrar que la decadencia se extendía a toda la edad moderna de nuestra historia [objective]

FR j'essayai de prouver qu'elle s'étendait à toute la période moderne de notre histoire [objective]

EN I tried to show that this decadence had been apparent during the whole of our history's modern period [objective]

In example (3) we find zero grounding in ST (España) and in the FR ( $l^{\prime}$ Espagne), but objective grounding in EN (here). In example (4) the zero grounding in ST (España) and in EN (Spain) is replaced by subjective grounding in FR (du pays).

(3) la opinión reiterada es, en parte, exacta; en España no ha habido apenas feudalismo [zero]

FR C'est exact : l'Espagne a, pour ainsi dire, ignoré l'organisation féodale. [zero] 
EN This time the commonplace is partially correct -there was hardly any feudalism here. [objective]

(4) Al contrario: la unidad se hizo tan pronto porque España era débil, [zero]

FR Au contraire, elle n'avait pu si soudainement se réaliser que grâce à la faiblesse $d u$ pays, [subjective]

EN On the contrary, the reason that unity was achieved with such speed was that Spain was weak [zero]

Example (5), finally, is more difficult to classify. In EN we find a case of zero grounding (they reached Spain). Compared to this form of zero grounding, the ST is qualified as subjective grounding, for the point of arrival is to be deduced from the implicit deictic centre of the narrator. FR, finally, is qualified as 'not equivalent', which in this context means simply that the structure is not sufficiently equivalent to compare the grounding status of the NP under examination.

(5) los visigodos, que arriban ya extenuados, degenerados, no poseen esa minoría selecta [subjective]

FR Déjà exténués, dégénérés, les Visigoths ne possèdent pas, eux, cette minorité d'élite. [not equivalent]

EN there was no such select minority among the Visigoths. By the time they reached Spain, they were a weakened and degenerate people. [zero]

In Table 1, the quantitative results are summarized. It is important to note that the totals between brackets are only indicative, because 'subjective grounding' and, obviously, 'not equivalent' do not function as selection criteria. These examples are only included when they correspond to an objective or zero grounding device in one of the other texts. 
Table 1: summary of the quantitative results of the grounding type in ES ST (rows), FR TT (upper half) and EN TT (lower half)

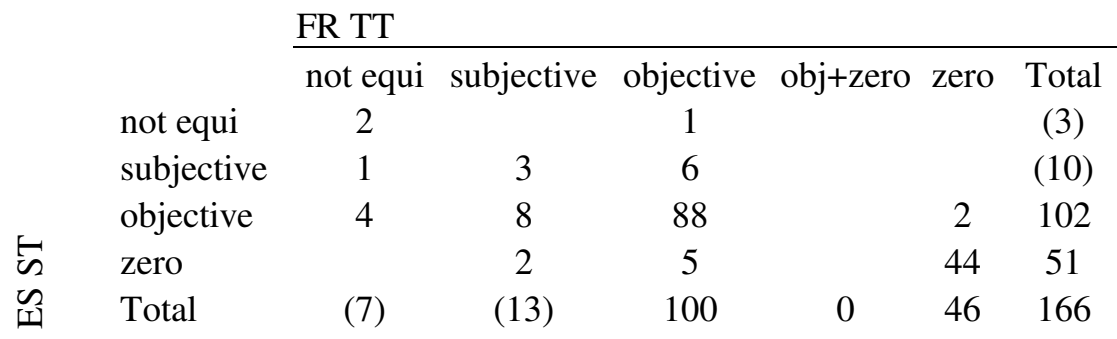

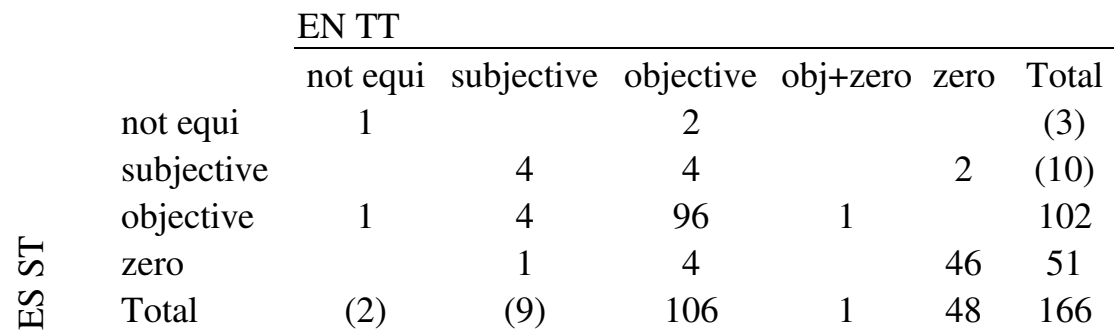

\subsection{Discussion : dimensions of similarity}

The following discussion is influenced by Chesterman (2007), who observes that recent descriptive TS usually focuses on differences, rather than on sameness or similarity. Since equivalence is what we expect, TS is more interested in the 'unexpected' differences, and pays more attention to describing and classifying types of differences than to similarity. Following Chesterman's suggestion, I will use the concept of similarity as guiding principle for the analysis. Similarity will be an explanatory principle for both superficial sameness and superficial divergence.

\subsubsection{Similarity and objective grounding}

The default strategy is clearly to maintain the same grounding category as was used in the ST. This happens in $86 \%$ of the examples of objective and zero grounding in FR and in $93 \%$ of EN cases. Changes are not frequent, although many cases are theoretically possible, see example (2) above or (6):

(6) El secreto de la desdicha española está en la Edad Media. (§29) [zero]

FR Le secret du malheur de l'Espagne se trouve dans le moyen âge. [notre malheur] [zero] 
EN The secret of Spanish misfortune lies in the Middle Ages. [our misfortune] [zero]

This is especially meaningful when we look at the objective grounding devices, because a possible prediction could be that objective grounding (our land, our history) will at least now and then be replaced by zero grounding (Spain, Spain's history), and thus will be less frequent in TT than in ST. Although this may be the case for FR (100 cases of objective grounding versus 102 in ES), it is not corroborated by the findings in EN (106). Zero grounding is also maintained in the vast majority of the examples, although we do see a slight decrease of the total number of cases in both TTs (ST 51, FR 46, EN 48). From this point of view, not only ST and TT are similar, but both TTs are similar to one another as well.

Let us now look at some examples where the TTs are similar in that they show the same difference with respect to the ST. In (7) and (8), both translators substitute subjective grounding by objective grounding. The translators presumably felt that the subjective grounding of el pasado nacional (the national past) and aquellos momentos (those moments) could be more easily interpreted by the TT reader if another grounding device was used. Interestingly, the translators do not choose a zero grounding device (Spain/Spanish) but an objective grounding device (we, our).

(7) Puede afirmarse que casi todas las ideas sobre el pasado nacional que hoy viven alojadas en las cabezas españolas son ineptas (\$10) [subjective]

FR Presque toutes nos idées, quant à notre passé, sont, on peut l'affirmer, ineptes et souvent grotesques. [objective]

EN Almost all the ideas about our national past which float in Spanish heads are inaccurate, [objective]

(8) Este fenómeno explica toda nuestra historia, inclusive aquellos momentos de fugaz plenitud. (\$9) [subjective]

FR phénomène qui explique notre histoire tout entière, même dans ses moments fugitifs de plénitude. [anaphoric relation to objective grounding]

EN This phenomenon explains our whole history, even including those fleeting moments of plenty when we were at our best. [objective]

I did not find examples where both TTs use zero grounding as an alternative rendering of subjective grounding. This is confirmed by the fact that ST subjective grounding is more often replaced by TT objective grounding (FR 8, EN 4) than by TT zero grounding (FR 0, EN 2). With respect to the alternation between objective and zero grounding (9), both translations substitute zero grounding by objective grounding more frequently (FR 5, 
EN 4) than vice versa (FR 2, EN 0). Clearly, it is not possible to argue that this shift is made to avoid ambiguity:

(9) [...] la caquexia del feudalismo español significa que esa ausencia fue inicial; [\$25] [zero]

FR La cachexie de notre régime féodal signifie que le mal a existé dès notre berceau [objective]

EN The enfeebled state of Spanish feudalism indicates that this absence existed at the beginning; [zero]

Summarizing, similarity is predominant in both translations. At first sight, this is more 'surprising' with respect to objective grounding than to zero grounding, for zero grounding does not depend on the deictic centre and is therefore more or less 'insensitive' to translation. Objective grounding requires that the TT reader evokes the ST ground (as part of the focus), but this seems no objection to use it. The empirical data even show an opposite trend. Examples were found where both translations make the same choice for objective and not for zero grounding to render a possibly ambiguous or more difficult interpretation, and a similar trend was observed in both translations to substitute zero grounding by objective grounding and not vice versa. These data raise the question whether objective grounding and similarity may be related on a more fundamental level. In section 3.3.3 and 3.3.4, I will argue that this is the case, but first we will look at the degrees of similarity.

\subsubsection{Degrees of similarity}

Although the TTs show important similarities, it is also true that similarity is more prevalent in EN (93\%) than in FR (86\%). Especially with respect to ST objective grounding, we find that the trend to maintain the grounding type is stronger in EN $(96+1$ or $95 \%)$ than in FR ( 88 or $86 \%)$.

Moreover, in the few cases where objective grounding is lost in EN, this change seems to have minor semantic consequences. Take example (10), where the objective grounding of the speech event participants through the explicit mention of the first plural is lost in EN, and rendered by a subjective construal ${ }^{4}$ but the interpretive consequences are clearly limited.

\section{(10) Pero dejemos esto. (\$30) [objective] \\ FR Mais laissons ce sujet. [objective] \\ EN But enough of this. [subjective]}

In FR, objective grounding is substituted more frequently by another form of grounding than in EN, and in addition, there are more cases where this has an impact on the interpretation process. Take example (11), where Ortega y Gasset uses the objectively grounded nuestra ignorancia (our ignorance), which is rendered in FR by the subjectively grounded l'ignorance 
générale and not by notre ignorance. In this example, the reader of the TT will have to make a more elaborated effort to anchor the NP to the deictic centre of the ST, identifying it as the ignorance of the Spaniards, or perhaps the reader will even anchor it to a wider perspective and not restrict it to Spain.

(11) lo importante, lo maravilloso, fue la colonización. A pesar de nuestra ignorancia sobre ella, nadie puede negar sus dimensiones como hecho histórico de alta cuantía. (§36) [objective]

FR Et cependant, le miracle, et le miracle transcendant, ce ne fut pas la conquête [..] ce fut la colonisation. En dépit de l'ignorance générale, nul ne s'avisera de nier l'importance d'un tel fait historique. [subjective]

EN I must insist that the important, the marvelous thing was colonization. In spite of our ignorance about it, no one can deny that it was an historic event of the first rank. [objective]

These data suggest that ST objective grounding devices are treated by the EN translator as almost untouchable phenomena. The FR translator treats them with more flexibility, using other expressions more regularly. In the EN translation similarity seems to have a more imperative character, at least to the extent that translation of objective grounding is concerned.

Example (12) is a good illustration of this difference between EN and FR. In the ST a contrast is established between France and England (the cultures of the TTs), and Spain. The ST refers to France and England with zero grounding (Francia/Inglaterra), and to Spain with the objective grounding device aquí. When we look at the TTs, we see that both translators change the last grounding device, presumably because they considered that aqui was insufficient to mark the contrast with the TT reader's culture. FR opts for en Espagne. EN, however, chooses to combine both strategies, emphasizing the contrast with zero grounding (Spain), but without losing the objective grounding device (here).

(12) Mientras la historia de Francia o de Inglaterra es una historia hecha principalmente por minorías, todo lo ha hecho aquí la masa, [objective]

FR Tandis que l'histoire de France ou celle d'Angleterre est, avant tout et surtout, l'oeuvre des minorités, en Espagne, c'est la masse qui a tout fait, [zero]

EN The history of France or of England is a history created chiefly by select minorities. Here in Spain it is the masses which have done everything, [objective+zero] 


\subsubsection{Similarity at the product level and the process level}

In the preceding chapters, I described the similarity between TTs and their ST, and the role that objective grounding plays in this context. We have also seen that there are degrees of similarity, since EN respects the similarity involving objective grounding more strictly. In what follows, I will proceed in a different way, and unravel similarity. First, I will suggest looking at similarity not only as it is manifested in the translation $\operatorname{product}(s)$, but also at what it means in the (documentary) translation process.

As I have explained in 1.2, in documentary translation the original communicative act is re-created, and the deictic centre of the ST is adopted. In this context, similarity as a process consists of the cognitive exercise of conceptualizing and communicating a certain scene from the deictic centre of the ST implied author. I would like to argue now that certain shifts that are visible in the translation product in fact should not be interpreted as symptoms of difference, but rather as symptoms of similarity at the process level.

In my view, this is the case when objective grounding devices are added in the documentary TT. When the translator adds expressions (= difference) such as our land or my opinion, these shifts may be interpreted as symptoms of the cognitive effort on behalf of the translator to adopt the ST deictic centre and to achieve process similarity. The profiled status of the ground at the surface level (= objective grounding) reflects in a certain sense the prominent status of the ST deictic centre within the essayistic documentary translation process.

When we compare the number of cases where objective grounding is added and omitted, we find that in FR, the situation is more or less balanced (12 additions -14 omissions). In EN, on the contrary, there are clearly more additions (10) than omissions (5). As a descriptive conclusion, I think that we can say that, although both translations are characterized by similarity, this similarity is 'marked' in EN: it is more clearly manifest at the surface level, and in the cases where important differences are observed at the surface level, these can be linked with similarity at the process level.

\subsubsection{Similarity in the translation process: between empathy and anxi- ety}

Taking it one important step further, and leaving the secure field of description, we might speculate about what the findings say about the translator. Does similarity mean, for example, that the translator feels empathy with the implied author, and therefore respects the ST deictic centre very carefully? Or is it more complex than that? In what follows, I will try to answer this question by looking at other phenomena in the translated texts. These data suggest that the similarity in EN might not be a symptom of empathy, but rather of an almost anxious intent to grasp the ST deictic centre. 
The first element is that, in EN, several interpretation problems are easily identified. In (13), que no se haya espumado is translated by Spain has never shaken off, but in fact, espumar (litt. to skim off) is used here metaphorically. The agent of the action is not Spain, but history writers who did not observe or detect some characteristic feature of Spain.

(13) En cuanto a España... Es extraño que de nuestra larga historia no se haya espumado cien veces el rasgo más característico, [...]: la desproporción casi incesante entre el valor de nuestro vulgo y el de nuestras minorías selectas. $(\S 4)$

FR Quant à l'Espagne... Il est surprenant que, de notre longue histoire, on n'ait pas écumé cent fois le trait le plus caractéristique, [...] : la disproportion presque incessante entre la valeur du vulgaire et celle des minorités de choix.

EN As for Spain, it is strange that throughout our long history Spain has never shaken off its most characteristic feature, [...], the almost constant disproportion between the worth of our common people, and that of our select minorities.

In (14) there are two interpretation problems. The image of condensación virtual means that the masses do not create history directly, but through some institutions, which concentrate the ideas or creativity (in this sense, they make the masses 'more dense'). In EN, a strange explanation is added comparing this process with live particles of steam in a boiler (the physical process of condensation), but it is clear that this does not clarify the ST meaning. Moreover, in the same context milenarias (millennial, very ancient) is translated as thousands, which is a confusion with miles or millares (thousands).

(14) Mientras la historia de Francia o de Inglaterra es una historia hecha principalmente por minorías, todo lo ha hecho aqui la masa, directamente o por medio de su condensación virtual en el Poder público, político o eclesiástico. Cuando entramos en nuestras villas milenarias vemos iglesias y edificios públicos. (\$7)

FR Tandis que l'histoire de France ou celle d'Angleterre est, avant tout et surtout, l'oeuvre des minorités, en Espagne, c'est la masse qui a tout fait, directement ou par condensation virtuelle dans le Pouvoir public, politique ou ecclésiastique. Dans nos villes millénaires, nous voyons des églises et des édifices publics ;

EN The history of France or of England is a history created chiefly by select minorities. Here in Spain it is the masses 
which have done everything, either directly, or by virtue of being condensed, like live particles of steam in a boiler, into Church and State. When we enter our thousands of small towns we instantly become aware of churches and public buildings.

As we can see in these examples, the EN translator had much difficulty in interpreting the (sometimes rather abstract) essay. Moreover, the translator was conscious of these difficulties, as is clear from the fact that some mistakes arise when the translator adds an explanation.

Apart from the interpretation errors, we find that the EN translator frequently adds (felicitous) explanations when the ST is obscure. The underlined fragments in (15) and (16) do not appear in the ST.

(15) Muy diferentes en otra porción de calidades, coinciden Rusia y España en ser las dos razas «pueblo»; esto es, en padecer una evidente y perdurable escasez de individuos eminentes. (\$3)

FR Fort différentes sur beaucoup d'autres points, la Russie et l'Espagne offrent ceci de commun qu'elles sont les deux races "peuple », souffrant du manque évident et permanent d'individualités éminentes

EN Very different in other qualities, Russia and Spain are alike in being the two "pueblo" races, races where the common people predominate- that is, races that suffer from an obvious and continuous lack of eminent individuals.

(16) El rey, que originariamente no era sino el primero entre los iguales, «primus inter pares», aspira de continuo a debilitar esta minoría poderosa. Para ello se apoya en el «pueblo» y en las ideas romanas. (\$21)

FR Le roi, d'abord simplement le premier e ntre ses pairs, primus inter pares, ne cesse d'aspirer à l'affaiblissement de cette minorité toute-puissante et, pour cela, de s'appuyer sur le «peuple » et les idées romaines.

EN The king. who was originally only the first among equals, "primus inter pares," constantly sought to lessen the power of this select minority. For this purpose he invoked the aid of the people and of the Roman ideas, as opposed to the Germanic.

In my opinion, it is possible to see a link between the 'marked similarity' in the EN translation of the (objective) grounding devices, the interpretation problems and the overall strategy of the EN translator to add explanations. 
The errors and explanatory additions reveal that the EN translator is uncertain whether she conceptualized the scene as it was meant by the ST implied author. In addition, they reveal that the translator doubts whether or not the TT implied reader will grasp that scene as it was meant by the ST implied author (and presumably interpreted by the ST implied reader). The identification with the implied author's voice is problematic, for both the translator and the TT implied reader.

The marked similarity of the grounding expressions in EN can now perhaps be interpreted as linguistic symptoms of how the translator handles this uncertainty. Concretely, they could be symptoms of an intent to stabilize an unsteady ground and of a psychological anxiety to grasp the original ground. By profiling the ground through objective grounding expressions, the translator seems to secure the anchors of the (problematic) ST deictic centre.

In the FR translation, there are no examples of explanatory paraphrases, or misunderstandings like (13)-(16). Does this mean that the real translator did not have any interpretation problems? Not necessarily. Perhaps the similarity between the two language systems allowed the translator to formulate the same message almost word-for-word, while the EN translator could not mask the interpretation problems (see for example FR (13) and (14)). The only thing that we know is that the possible conceptualization problems do not become visible, and, hence, as TT readers (or TT critics) we think that the implied translator was convinced of having achieved similarity with the ST communication. The link with the real translator is that the implied translator is not only an image in the mind of the TT reader, but also in the mind of the real translator him/herself: it is the way in which the translator thinks that his/her work will be perceived by the TT reader. In this sense, the FR translator seems to believe that the TT reader will have the impression to be witnessing the ST communicative act. If certain fragments are rather obscure, the FR translator seems to believe that the TT reader will attribute this to the ST implied author and not to the implied translator.

Summarizing, in FR similarity seems to be more self-evident than in EN. Is this because the real translator feels more empathy with the implied author? Or is it because the language systems make it easier to create the illusion of similarity? Or a combination of both? In fact, it hardly matters for this analysis, what does matter is that similarity seems self-evident for the FR implied translator and not for the EN implied translator. My claim is then that the real translators are influenced by their own image of the implied translator, and that this influence becomes visible at other points of the text, concretely in the way that both translators treat objective grounding. While the EN translator uses these profiled references to the ground as a stabilizing (or perhaps compensating) factor for the unstable conceptualizing ground, the FR translator handles them with more flexibility, presumably because she has less need to secure the ground. 
I will conclude by commenting on two final examples that may illustrate more empathy in the FR translator than in the EN translator. In example (17), Ortega y Gasset widens the perspective when he says nuestras naciones (our nations), including not only Spain but France and England as well (see also 12). In FR, this is rendered with subjective grounding. As such, FR allows the implied author to include the TT culture in the grounding, although not in its focused form. In EN, on the contrary, the objective grounding is maintained but the singular is used (our nation), which has a major effect, since it excludes the TT culture England.

(17) Pues bien: lo que en la sociedad actual representa la minoría de superior intelecto fue en la hora germinal de nuestras naciones la minoría de los feudales. (\$23) [objective]

FR Or, ce que représente dans notre société une minorité d'intelligences supérieures n'est autre chose que ce que représentait, à l'époque où se formaient les nations actuelles, une minorité de seigneurs féodaux. [subjective]

EN Transport the intelligent minority in modern society back through the centuries to the moment when our nation was being born, and you will find that they there constitute the select minority of the feudal lords. [objective -singular!]

Also in (18), Ortega y Gasset refers to France and England with the subjectively grounded las demás [naciones] (the other nations). In FR this is basically maintained, although the subjective grounding is now anchored to a form of objective grounding (les nations ... que nous). As in (17), FR allows including the TT culture in the grounding mechanism of the ST implied author. In EN, this is again not the case. Now the translator uses an indefinite form (other nations), which ensures that the reader is no longer supposed to identify these nations.

(18) La ausencia de los «mejores», o, cuando menos, su escasez, actúa sobre toda nuestra historia y ha impedido que seamos nunca una nación suficientemente normal, como lo han sido las demás nacidas de parejas condiciones.

FR L'absence des «meilleurs » ou, tout au moins, leur nombre réduit se fait sentir dans notre histoire tout entière et nous a empêchés d'être une nation normale, comme les nations nées dans les mêmes conditions que nous.

EN The absence of the "best people," or at least their scarcity, runs through our whole history and has kept us from ever being like other nations under similar conditions, a completely normal people. [uninstantiated subjective grounding]

What (17) and (18) have in common is that EN avoids the TT culture in the grounding of the text. This means that the point of view of the ST implied 
author is emphasized (remember the marked status of the objective grounding) but also more clearly restricted to its ST culture domain than in the FR translation.

\section{References}

Bosseaux, Charlotte (2007). How Does it Feel? Point of View in Translation. The Case of Virginia Woolf into French. Amsterdam: Rodopi.

Brisard, Frank (2002). Introduction: The Epistemic Basis of Deixis and Reference. F. Brisard (ed.) (2002). Grounding: The Epistemic Footing of Deixis and Reference. Berlin: Mouton de Gruyter, xi-xxxiv.

Chatman, Seymour (1978). Story and Discourse: Narrative Structure in Fiction and Film. Ithaca: Cornell University Press.

Chesterman, Andrew (2007). Similarity Analysis and the Translation Profile. W. Vandeweghe, S. Vandepitte and M. Van de Velde (eds) (2007). The Study of Language and Translation. Special Issue of Belgian Journal of Linguistics 21, 53-66.

Herman, David (2002). Story Logic. Problems and Possibilities of Narrative. Lincoln/London: University of Nebraska Press.

Koster, Cees (2000). From World to World. An Armamentarium for the Study of Poetic Discourse in Translation. Amsterdam: Rodopi.

Langacker, Ronald (2002). Deixis and Subjectivity. F. Brisard (ed.) (2002). Grounding: The Epistemic Footing of Deixis and Reference. Berlin: Mouton de Gruyter, 1-28.

Munday, Jeremy (2008). Style \& Ideology in Translation. Latin American Writing in English. London: Routledge.

Nord, Christiane (1997). Translating as a Purposeful Activity. Manchester: St-Jerome.

O'Sullivan, Emer (2003). Narratology meets Translation Studies, or, The Voice of the Translator in Children's Literature. Meta 48, 197-207.

Schiavi, Giuliana (1996). There is Always a Teller in a Tale. Target 8, 1-21.

Semlali, Hicham (2007). Translating deixis: A subjective experience. Unpublished $\mathrm{PhD}$ Thesis University of Edinburgh (http://hdl.handle.net/1842/1844).

Vandepitte, Sonia (2007). Semantic and Pragmatic Meanings in Translation. W. Vandeweghe, S. Vandepitte and M. Van de Velde (eds) (2007). The study of Language and Translation. Special Issue of Belgian Journal of Linguistics 21, 185-200.

1 I wish to thank my colleague July De Wilde and two anonymous referees for their comments. Their suggestions were not only helpful for the revision of this paper, but also offered very interesting ideas for future research.

2 Munday draws on the narratological scheme of Chatman 1978. It is beyond the scope of this paper to discuss alternative visions. See e.g. Herman (2002: 332-6) and Koster (2000: 19-22).

3 Of course, there may be exceptions, like in Kierkegaard's writings, where the essayistic narrator takes multiple forms and cannot be said to reflect Kierkegaard's opinion without running into contradictions.

${ }^{4}$ Following Langacker, this is a case of subjective grounding because (1) the speaker is the source of the illocutionary force, which is part of the meaning of the utterance and (2) there is no explicit reference to the speaker. 